\title{
KEPADATAN NYAMUK DEWASA AEDES SP DI KELURAHAN \\ MALALAYANG I KECAMATAN MALALAYANG MANADO PERIODE JANUARI - PEBRUARI 2010
}

\author{
Janno B. B. Bernadus \\ Victor D. Pijoh \\ Venny Kareth

\begin{abstract}
Bagian Parasitologi Fakultas Kedokteran Universitas Sam Ratulangi Manado Email: jannobernadusmd@yahoo.co.id
\end{abstract}

\begin{abstract}
Dengue Hemorrhagic Fever (DHF) has become a public health problem in Indonesia due to its high prevalence and ability to spread widely. In North Sulawesi itself, case fatality rates of DHF patients are increasing from year to year. The local village of Malalayang is an area with a high potential for the spread of this disease. The result of an entomological survey on adult mosquitos showed that Aedes $s p$ was found in 40 out of 80 house samples. From these 40 houses we got 71 adult mosquito samples. From these 71 samples tested and identified, we found three species: Aedes aegypti (30 samples, 42.25\%), Aedes albopictus (22 samples, 30.99\%), and Culex sp (19 samples, 26.76\%). Mosquito density can be seen from the indices of the resting rates, which were 0.375 for Aedes aegypti, 0.275 for Aedes albopictus, and 0.65 for Aedes sp.
\end{abstract}

Keywords: density, adult mosquito, Aedes $s p$., resting rate

\begin{abstract}
Abstrak: Demam Berdarah Dengue (DBD) merupakan penyakit yang menjadi masalah kesehatan masyarakat di Indonesia karena prevalensinya yang tinggi dan penyebarannya yang semakin luas. Di Sulawesi Utara, Case Fatality Rate penyakit DBD tercatat terus meningkat dari tahun ke tahun. Kelurahan Malalayang I merupakan daerah yang potensial sebagai daerah penyebaran DBD. Survei entomologi terhadap nyamuk dewasa Aedes sp pada 80 rumah memperlihatkan bahwa 40 diantaranya terdapat 71 sampel nyamuk. Setelah diperiksa dan diidentifikasi ternyata ditemukan tiga spesies yaitu Aedes aegypti 30 sampel (42,25\%), Aedes albopictus 22 sampel (30,99\%) dan Culex sp 19 (26,76\%). Kepadatan nyamuk dapat dilihat dari angka indeks pada resting rate yaitu Aedes aegypti $=0,375$, Aedes albopictus $=0,275$ dan Aedes sp. $=0,65$.
\end{abstract}

Kata kunci: kepadatan, nyamuk dewasa, Aedes sp., resting rate

Di negara-negara yang sedang berkembang termasuk Indonesia, penyakitpenyakit yang ditularkan melalui nyamuk masih merupakan masalah kesehatan yang cukup penting. Penyakit yang ditularkan melalui nyamuk tersebut antara lain Malaria, Demam Berdarah Dengue (DBD) dan filariasis (penyakit kaki gajah). Salah satu upaya pengendalian terhadap penyakitpenyakit tersebut yaitu dengan melakukan pengendalian terhadap vektor dari penyakit tersebut. Vektor penyakit yang sampai saat ini sering menimbulkan masalah kesehatan khususnya di Indonesia ialah nyamuk Aedes sp. Nyamuk Aedes aegypti merupakan vektor utama penyebab penyakit DBD di Indonesia. Vektor potensial lainnya yaitu Aedes albopictus. Penyakit ditularkan melalui gigitan Aedes $s p$ betina yang mengandung virus dengue dalam tubuhnya. ${ }^{1,-3}$

DBD telah menjadi masalah kesehat- 
an masyarakat di Indonesia karena prevalensinya tinggi dan penyebarannya semakin luas di seluruh Indonesia, termasuk di Sulawesi Utara. Kota Manado merupakan endemis demam berdarah. Jumlah desa terjangkit pada tahun 1994 adalah sebanyak 58 desa/kelurahan, menjadi 162 pada tahun 1999. Insidens rate DBD per 100.000 penduduk dari tahun ke tahun menunjukkan peningkatan. Penelitian ini bertujuan untuk mengetahui faktor sanitasi lingkungan terutama yang berhubungan dengan kejadian DBD di daerah Pesisir Pantai Manado. ${ }^{2}$ Kelurahan Malalayang I termasuk salah satu kelurahan Kecamatan Malalayang Kotamadya Manado yang penduduknya cukup padat yaitu 8762 jumlah total penduduk, dan jumlah kepala keluarga 2251. Kelurahan ini terbagi atas 11 lingkungan yang luas total wilayah kelurahan malalayang I yaitu $900 \mathrm{Ha}^{3}$

Kelurahan Malalayang I merupakan daerah yang potensial sebagai daerah penyebaran DBD karena di kelurahan ini cukup banyak terdapat tempat-tempat umum yang merupakan tempat berkumpulnya orang-orang yang datang dari berbagai daerah, seperti sarana pelayanan kesehatan yaitu: Rumah Sakit Umum Prof. DR. R.D. Kandou Malalayang, puskesmas, dan tempat-tempat umum lainnya seperti: hotel, rumah makan, sekolah, dan Fakultas Kedokteran Unsrat. Tempat-tempat umum ini memungkinkan orang datang dari berbagai wilayah dan kemungkinan diantaranya terdapat penderita DBD, demam dengue atau carrier virus dengue. Hal ini dapat dilihat pada data yang dilaporkan bulan Januari-Desember 2008 dimana jumlah kasus DBD yang dilaporkan di Kelurahan Malalayang I sebanyak 21 kasus. ${ }^{3-4}$

Menurut data yang di peroleh dari puskesmas Bahu, yaitu dari bulan JanuariDesember 2008 ternyata di beberapa lingkungan di Kelurahan malalayang I, terdapat kejadian DBD. Dari hasil data tersebut dapat dilihat bahwa DBD telah menyebar hampir di seluruh lingkungan di Kelurahan Malalayang I. Dengan melihat penyebaran penyakit DBD tersebut, maka harus dipikirkan pula tentang penyebaran vektor nyamuk. Hingga saat ini Aedes aegypti masih merupakan vektor utama penyakit $\mathrm{DBD}$, disamping vektor potensial lainnya yaitu Aedes albopictus.

Pada tahun 2002 telah dilakukan penelitian mengenai populasi larva Aedes aegypti di Kelurahan Malalayang I Kecamatan Malalayang. Hasil penelitian memperlihatkan $\mathrm{HI}=14,28 \%, \mathrm{CI}=7,30 \% \mathrm{BI}=$ $26 \%$. Hal ini menunjukkan bahwa penyebaran Aedes aegypti cukup tinggi di Kelurahan Malalayang I. ${ }^{4}$

Mengingat masih tingginya penyebaran DBD di Kelurahan Malalayang I, maka perlu dipikirkan untuk dilakukan pengendalian terhadap vektor DBD yaitu Aedes sp. ${ }^{4}$ Nyamuk Aedes aegypti telah diketahui sebagai vektor atau penyebar virus $\mathrm{DBD}$, tetapi obat atau vaksin terhadap virus tersebut sampai saat ini belum ditemukan. ${ }^{5-9}$

Untuk menunjang keberhasilan pengendalian vektor ini maka diperlukan survei entomologi DBD yang mengamati perkembangan dan habitat serta populasi dan kepadatan jentik/larva dan nyamuk dewasa. Pada survei entomologi DBD terdapat lima (5) kegiatan pokok yaitu: pengumpulan data terkait, survei telur, survei larva atau jentik, survei nyamuk dewasa dan survei lainnya. ${ }^{6}$ Survei nyamuk dewasa di Kelurahan Malalayang I sangat penting mengingat masih tingginya insiden DBD di daerah tersebut.

\section{METODE PENELITIAN}

Metode yang digunakan dalam penelitian ini adalah metode survei deskriptif untuk melihat kepadatan populasi nyamuk dan jenis-jenis nyamuk yang terdapat di lapangan.

Untuk menentukan besar sampel survei entomologi terhadap nyamuk dewasa digunakan pedoman survei entomologi DBD dari Depkes, yaitu sebanyak 80 rumah yang dibagi dalam empat strata/ kelompok. Setiap strata terdiri dari 20 rumah.

Alat dan bahan yang digunakan da- 
lam penelitian ini mikroskop stereo, loupe/kaca pembesar 10x atau 20x, aspirator, kotak nyamuk, kurungan nyamuk, pinset ujung runcing, jarum seksi, gunting kecil, sampel nyamuk, paper cub (cangkir kertas), kain kasa, karet gelang, kapas, kloroform, jarum serangga. Nyamuk yang ditangkap dibawa ke laboratorium Parasitologi Fakultas Kedoketran Unsrat untuk diamati dan diidentifikasi. Nyamuk ditangkap dengan aspirator lalu dimatikan dengan kloroform, dihitung jumlahnya, dan diidentifikasi jenis nyamuk dengan menggunakan kunci identifikasi dari WHO.,10 Untuk nyamuk Aedes $s p$ dibedakan jantan dan betina. Indeks nyamuk yang digunakan dengan menggunakan resting per rumah karena tidak adanya profilaksis untuk dengue.

Kepadatan dan penyebaran populasi nyamuk dewasa dapat diperkirakan dari angka indeks yang ada. ${ }^{6}$

\section{HASIL DAN PEMBAHASAN}

Dari sekitar 1585 rumah di daerah Kelurahan Malalayang diambil secara acak 20 rumah untuk setiap strata, dengan total 80 rumah yang diperiksa.

Setelah dilakukan penangkapan nyamuk ternyata dari total 80 rumah diperoleh 71 sampel nyamuk dari 40 rumah, sedangkan 40 rumah lainnya tidak terdapat nyamuk. Dari 71 sampel nyamuk yang diperiksa ternyata ditemukan tiga spesies: Aedes aegypti, Aedes albopictus dan Culex yang tersebar pada rumah-rumah tersebut. Jumlah dan jenis spesiesnya dapat dilihat pada Tabel 1.

Dari total 80 rumah, 40 rumah diantaranya tidak terdapat nyamuk. Hal ini mungkin disebabkan karena masyarakat di lingkungan tersebut sudah mengerti mengenai bahaya DBD dan cara pencegahannya. Keadaan lingkungan sekitar rumah-rumah tersebut bersih dan be bas sampah (sarang nyamuk), sistem ventilasi rumah yang baik (jendela dengan kawat kasa), dan memakai obat nyamuk bakar atau semprot sebelum tidur. Pada 40 rumah yang terdapat nyamuk, masyara- kat disitu belum mengerti mengenai bahaya demam berdarah. Hal itu dapat terlihat pada keadaan lingkungan sekitar rumah yang tidak bersih dari sampah yang merupakan faktor utama tempat bersarang nyamuk.

Tabel 1. Jumlah total nyamuk yang berhasil ditangkap.

\begin{tabular}{ccc}
\hline Species & Jumlah & $\%$ \\
\hline & & \\
Culex sp & 19 & 26,76 \\
Ae. aegypti & 30 & 42,25 \\
Ae. albopictus & 22 & 30,99 \\
\hline Total & $\mathbf{7 1}$ & $\mathbf{1 0 0}$ \\
\hline
\end{tabular}

Dari data diatas maka dapat dihitung indeks nyamuk resting per rumah (Tabel 2).

Tabel 2. Indeks nyamuk berdasarkan resting per rumah

\begin{tabular}{cc}
\hline Spesies & Indeks resting \\
\hline Ae.aegypti & 0,375 \\
Ae. albopictus & 0,275 \\
\hline
\end{tabular}

Dari 71 sampel nyamuk yang diperiksa dan diidentifikasi berdasarkan ciriciri morfologinya ternyata ditemukan tiga spesies: Aedes aegypti, Aedes albopictus dan Culex sp yang tersebar pada tiap-tiap rumah. Adapun jumlah nyamuk tiap species yang berhasil ditangkap antara lain Culex sp 19 (26,76 \%), Aedes albopictus 22 (30,99\%) dan Aedes aegypti 30 (42,25 $\%)$. Dari hasil penelitian terlihat bahwa species nyamuk Aedes aegypti yang merupakan vektor utama penyakit DBD di daerah ini masih dominan. Salah satu penyebab tingginya jumlah nyamuk Aedes $s p$ tersebut karena tingkat kebersihan yang kurang dari masyarakat sehingga banyak sampah baik organik maupun nonorganik yang berserakan di sekitar rumah (menjadi sarang nyamuk), serta masih kurangnya pemberantasan sarang nyamuk secara berkala. Hasil survei memperlihatkan bahwa kelompok masyarakat di daerah ini 
mempunyai kebiasaan mengumpulkan dan menumpuk barang bekas, baik di dalam maupun di luar rumah yang memungkinkan berkembangnya sarang nyamuk.

Masyarakat di daerah ini sering menguras bak mandi (setiap dua sampai tiga hari) karena sering air dari PT Air tidak jalan, namun kurang memperhatikan tempat penampungan air yang besar seperti drum dan tong air yang tidak ditutup atau hanya dikuras seminggu sekali; dari tempat ini masih ditemukan jentik nyamuk.

Didaerah ini juga masih terdapat bangunan-bangunan yang tidak dihuni dan dibiarkan oleh pemiliknya sehingga dapat menjadi tempat sarang nyamuk. Juga lingkungan sekitar yang kotor dan penuh dengan botol plastik memungkinkan perkembangan nyamuk Aedes sp.

Kebiasaan memelihara bunga juga menjadi kebiasaan masyarakat memungkinkan tempat perindukan dan perkembangan nyamuk Aedes sp.

Daerah pekuburan juga menjadi tempat perkembangan dan perindukan nyamuk Aedes sp. Kebiasaan masyarakat membawa bunga segar di makam dengan menempatkannya dalam wadah atau vas bunga, dapat menjadi tempat perkembangbiakan nyamuk. Daerah pekuburan juga sering dibiarkan sehingga banyak genangan air yang dapat menjadi sarang nyamuk.

Kemungkinan Aedes sp di daerah Malalayang untuk menjadi vektor juga sangat besar mengingat bahwa lokasinya dekat dengan Puskesmas dan Rumah Sakit Umum Pusat Prof. DR. R.D. Kandou yang menjadi rujukan Perawatan DBD di Manado dan sekitarnya. Pada penelitian ini belum dilakukan pengujian vektor DBD sehingga belum diketahui seberapa besar potensi nyamuk Aedes $s p$ yang dapat menjadi vektor DBD.

Hasil penelitian ini juga sesuai dengan penelitian yang di lakukan pada tahun 2002 tentang populasi larva Aedes aegypti di Kelurahan Malalayang I Kecamatan Malalayang, yaitu $\mathrm{HI}=14,28 \%$, $\mathrm{CI}=7,30 \%$, dan $\mathrm{BI}=26 \%$. Hal ini menun- jukkan bahwa penyebaran Aedes aegypti cukup tinggi di Kelurahan Malalayang I. ${ }^{4}$ Dengan tingginya jumlah populasi nyamuk Aedes sp maka dapat memengaruhi kejadian kasus DBD. Hal ini dapat dilihat pada data yang dilaporkan bulan Januari Desember 2008 dengan jumlah kasus DBD di Kelurahan Malalayang I sebanyak 21 kasus yang di laporkan.

\section{SIMPULAN}

Di Kelurahan Malalayang I masih terdapat banyak rumah yang ditempati oleh nyamuk Aedes aegypti dan Aedes albopictus.

\section{DAFTAR PUSTAKA}

1. Sungkar S. Demam Berdarah Dengue. Jakarta: FKUI Berkelanjutan dan Ikatan Dokter Indonesia, 2004.

2. WHO. Palupi W, alihbahasa. Pencegahan dan pengendalian Dengue dan Demam Berdarah Dengue: Panduan Lengkap. Jakarta: EGC, 2004.

3. Data Kependudukan Kelurahan Malalayang dan Data Penderita DBD (Demam Berdarah Dengue) di Kelurahan Malalayang I, Kecamatan Malalayang Manado. Manado: Lurah Malalayang I, 2009.

4. Sentinuwo A, Runtuwene J, Kapojos F. Populasi larva Aedes aegypti di Kelurahan Malalayang I Kecamatan Malalayang Manado, periode Mei-Juli 2001. Manado: KTIS FK UNSRAT, 2001

5. Hendarwanto. Dengue. In: Sjaifoellah Noer NR, editor. Buku Ajar Ilmu Penyakit Dalam Jilid 1 (Edisi ketiga). Jakarta: Gaya Baru, 2004; 417-8.

6. Departemen Kesehatan RI. Pedoman Survei Entomologi Demam Berdarah Dengue (Cetakan ke-2). Jakarta: Depkes RI, Direktorat Jenderal Pemberantasan Penyakit Menular dan Penyehatan Lingkungan, 2002.

7. Mansjoer A. Kapita Selekta Kedokteran FKUI (Edisi ke-3). Jakarta: Media Aesculapius, 2001.

8. Gandahusada S, Ilahude HHD, Pribadi W. Parasitologi Kedokteran (Edisi ketiga). Jakarta: FKUI, 2003. 
9. Sembel DT. Entomologi Kedokteran (Edisi I). Yogyakarta: C.V. Andi Offset, 2009.
10. Huang. Key to Species of Aedes (Stegomya) in WHO/VBC 74.5.doc. Jakarta: FKUI (copied), 1972; 47. 